\title{
$\mathrm{AHS}$ 에서 차량군의 속도와 거리 변화에 따른 운전자의 생체신호와 감성 평가
}

\section{The Evaluation of Driver's Physiology Signal and Sensibility according to the Change of Speed and the Gap of Platoon on AHS}

\author{
전용욱*, 박 범**
}

\begin{abstract}
The one of the most important factors is the platoon design on developing AHS(Advanced Highway System), as it is related to traffic efficiency and drivers' safety. This study was evaluated that how much speed is comfortable for drivers and how long distance is appropriate for vehicular gap of platoon by measuring drivers' physiology signal and sensibility. A fixed-based AHS simulator was developed by using a real vehicle cockpit and the restructured part of Korean highway for human factors evaluation. The EEG(electroencephalogram), ECG (electrocardiogram) and GSR(Galvanic Skin Response) were measured for obtaining drivers' physiology signal according to the change of speed and gap. The brain wave $(a, \beta, \delta, \theta)$ by EEG, the response of the autonomic nervous system, the sympathetic and parasympathetic nervous system. by ECG. and relax-arousal situation by GSR were analyzed. The SD(Semantic Differential) method was also applied to evaluate drivers' sensibility by 5 -grade evaluation scale with 96 adjectives. SSQ(Simulator Sickness Questionnaire) was used to measure the simulator sickness of pre and post driving, two times. As the results, drivers were comfortable with $120 \mathrm{~km} / \mathrm{h}$ speed of platoon and $10 \mathrm{~m}$ to $15 \mathrm{~m}$ vehicular distance. The results of this study may differ from the adaption of the reality because of many parameters. However, the purpose of this study is show to significant results of the drivers' safety and the acceptability of human factors evaluation.
\end{abstract}

Keyword: ITS, AHS, platoon, physiology signal, SD method.

* 아주대학교 산업공학과 대학원

** 아주대학교 산업공학과 부교수 


\section{1. 서 론}

\section{1 연구의 목적 및 필요성}

인간공학의 관점에서 $\mathrm{AHS}$ (Advanced Highway System)는 사용자로서의 인간, 도구로서의 자동차, 운용환경으로서의 도로 및 교통시스템으로 구성된 Man-Machine 시스템으로서 기존의 교통시스템과는 구별되 는 새로운 환경친화적인 운전자-자동차-도로 시스템으로 정의할 수 있다. 이러한 AHS의 설치에 따른 교통측면의 이점은 경제적 측면 에서 차선당 2-3배의 시간당 차량대수의 증 가와 30 -50\%의 주행시간 단축 효과가 예상 되며, 이로 인한 연료 소비의 감소와 배기가 스 방출의 축소로 환경적인 이점 또 한 가지 고 있다.

또, $50 \sim 80 \%$ 의 교통사고가 감소할 것으로 예측되어 안전적인 측면에서 상당한 효과를 가져다 줄 수 있다(Anthony Hitchcock, 1995). 이러한 AHS의 기대효과는 ITS (Intelligent Transport System)의 가장 핵심적인 연구 분야로 취급받고 있어 $\mathrm{AHS}$ 의 표준화를 만들고 있는 실정이다. 그러나 $\mathrm{AHS}$ 는 미래교통 수단의 하나의 대안으로 떠 오르고 있지만, 사전 설계에서 인간공학적인 연구 없이는 $\mathrm{AHS}$ 운전자의 한정된 인간성능 및 기능에 혼란 및 부하를 가중시키게 되므로 운전자의 인지적 혼란과 사고의 위험을 증대 시킬 수 있다. 실제 교통사고의 많은 부분이 인간의 한계를 고려하지 않은 인터페이스에서 주로 발생하며, 디스플레이 및 제어장치의 표
준화 부족과 인간정보 인지모델에 일치하지 않는 인간공학적 설계의 미비에 있다. 이러한 사실은 $\mathrm{AHS}$ 를 위한 인간 대상 연구의 중요 성과 인간공학의 필요성을 대변하고 있다.

\section{$1.2 \mathrm{AHS}$ 의 인간공학적 연구의 필요성}

$\mathrm{AHS}$ 는 여러 가지 교통의 복잡한 상황이나 매우 나쁜 날씨에서도 운전이 가능하도록 하 며, 최첨단 시스템이 교차로의 병목과 분리를 제어하고, 주행시 차선 변경이나 익숙하지 않 은 도로에서의 운전에서 유용하다고 연구되고 있다(Bin Ran etc.). 그러나 AHS의 최우선 적 목적은 고속도로에서의 자동차 수용 용량 의 증대와 속도 제어에 의한 승차자의 안전이 라 할 수 있을 것이다. 이러한 면에서 인간공 학적 연구는 운전자의 자동차 조작형태와 도 로 상황, 도로 교통물의 설계와 기능적 설계 를 도와주며. 운전자-자동차-도로 간의 인터 페이스 등 매우 중요한 역할을 담당한다. 이 것은 운전자의 수용성과 수행도를 고려하여 반드시 AHS 초기 설계에서뿐만 아니라 개념 적 설계 단계에서 완벽한 보완을 해야 한다는 것을 의미한다. 따라서 $\mathrm{AHS}$ 는 인간에 맞는 완전한 시스템으로써 운전자들에게 쉽게 사용 이 가능하고, 편안히 받아지도록 설계가 된다 면, $\mathrm{AHS}$ 에서 인간 오류에 의하여 유인된 사 고를 제어하여 고속도로에서의 안전을 향상시 킬 수 있는 것이다.

$\mathrm{AHS}$ 개발단계에서 가장 중요한 요소 중의 하나는 차량군(platoon) 내에서의 차량간의 간격과 차량군의 속도이며. 이들은 교통 효율 과 고속도로 용량 문제에 갚이 관련되어져 있 
다. 차량군에서의 여러 모수들도 중요한 문제 점이긴 하나 차량군에서의 속도와 간격은 운 전자의 안전을 위험과 분리시키고, 수용성 및 사용 적합성 등 정신적 반응을 평가하기 위하 여 상당한 문제점으로 작용될 것으로 사료된 다. 따라서 본 연구에서는 인간공학 평가를 위한 AHS 차량 시뮬레이터를 구축하여, $\mathrm{AHS}$ 에서 자동주행 시 차량군 내의 차량 간 속도와 거리의 변화에 대하여 운전자가 느끼 는 생체신호와 감성 평가를 하였다. 이를 통 하여 인간에게 가장 적합하고, 감성에 맞는 속도와 거리를 평가하였다.

\section{2. 연구 목적}

본 연구는 $\mathrm{AHS}$ driving simulator를 이 용하여 자동주행 구간에서의 운전자의 자율신 경계 반응에 대한 $\mathrm{EEG}$ (electroencephalogram), ECG(electrocardiogram)과 GSR (Galvanic Skin Response) 등 생체신호의 측정 - 분석을 통한 정량적 분석방법과 감성형 용사의 의미미분법(Semantic Differential Method)을 이용한 정성적 분석방법으로 차 량군의 속도 및 거리 분석을 통하여 인간에게 가장 적합한 설계 가이드를 세우는 데 초점을 두었다.

개발 시뮬레이터의 도로구성은 경부고속도 로의 한 구간을 실제 모니터링 하여 실험목적 에 맞도록 재구성하였다.

\section{1 평가용 AHS Simulator 구축}

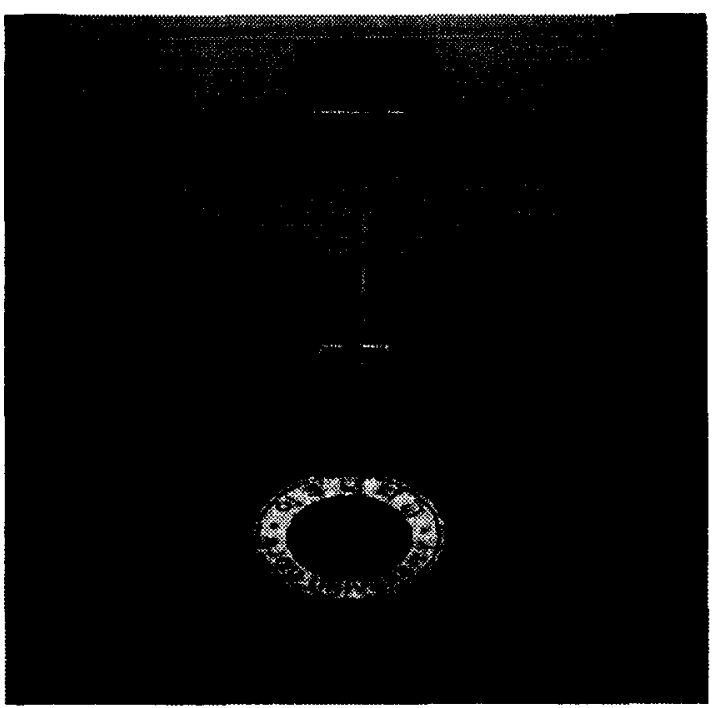

그림 1. 개발된 AHS Driving Simulator

AHSS(AHS Simulator)는 seating buck과 cockpit으로 구성된 실제 승용차 $(\mathrm{H}$ 사 V차량, automatic transmission)를 사 용하였고, 16 자유도의 동적 시뮬레이터 모 델을 사용하였다. 그림 1 은 개발된 평가용 AHS simulator를 보여준다. HUD (Head-Up Display)와 AHS 정보들은 TCP (Transmission Control Protocol)를 사용하여 자동차 상태와 정보를 동시적으로 운전자가 볼 수 있도록 하였고, LCD project를 사용하여 도로환경을 제시하였다. 사용된 도로환경은 $\mathrm{AHS}$ 환경의 사실적 묘사 를 위하여 경부고속도로의 오산에서 천안 구 간 $($ 약 $38 \mathrm{~km})$ 을 비디오 촬영 후 AHS 실험 목적에 맞도록 수정하였다. 설비된 도로구조 는 'Shared At-Grade Concept' 으로 두 
수동주행 구간(ML)과 하나의 차선변경 구간 (TL), 하나의 자동주행 구간(AL)으로 나누 어졌다. AHS Driving Simulator는 AHS 구간에서 자동차의 속도를 $120 \sim 180 \mathrm{~km} / \mathrm{h}$ 로 제어할 수 있고, 차량군 간의 간격을 5 $20 \mathrm{~m}$ 까지 메인 컴퓨터로 쉽게 제어 및 설정 할 수 있도록 하였다. 그림 2는 시뮬레이터 주행 장면을 보여주며, 속도 및 차량정보는 HUD의 효과를 주었다. 표 1은 시뮬레이터 의 전체 주행 구간과 시간을 나타내었다.

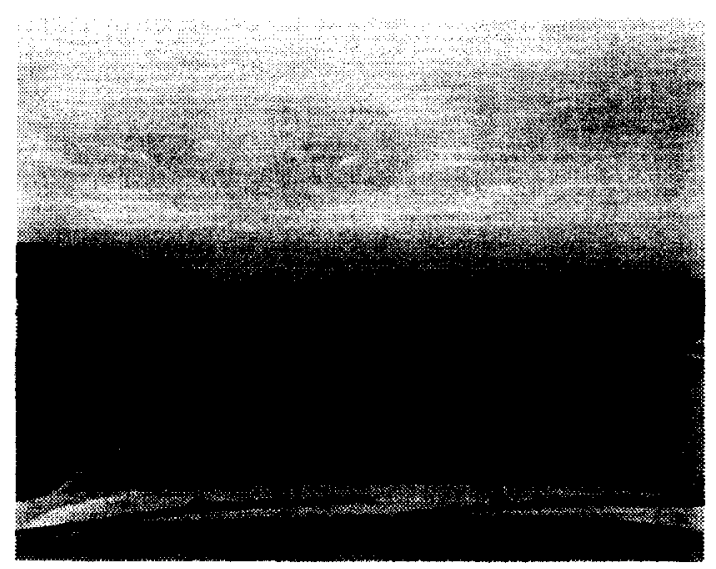

그림 2. 자동 주행 장면

\begin{tabular}{|c|c|c|c|}
\hline 구간 & 수동 주행 & 자동 주행 & 수동 주행 \\
\hline 길이 & $7 \mathrm{~km}$ & $25 \mathrm{~km}$ & $7 \mathrm{~km}$ \\
\hline 시간 & 5 분 & 15 분 & 5 분 \\
\hline
\end{tabular}

표 1. Simulator 주행 구간

\subsection{AHS에서 차량군 내의 차량간 속도 및 거리 평가}

AHS 차선은 그 비용과 기술적 한계에 의
하여 모든 도로상의 설치가 아닌 특정구간에 서의 운용이 계획되고 있다. 따라서 개발된 Simulator는 AHS 차량이 수동주행 구간에 서 변환 구간을 거쳐 자동주행 차선으로 진입 한 후 자동주행 구간에서의 $3 \sim 7$ 대의 차량군 과 합류되도록 하였다.

수동주행 구간에서는 안전을 위하여 앞차와 의 간격을 크게 두기 때문에 답답함을 느끼지 못하지만, 자동 주행 시에는 앞차와의 거리가 좁기 때문에 운전자 및 동승자가 답답함이나 불쾌감 등을 느낄 수 있다. 따라서 본 연구는 $\mathrm{AL}$ 구간의 주행 시 운전자가 가장 편안하게 느낄 수 있는 차량군의 속도와 거리를 평가하 였으며. 제시된 시뮬레이터를 이용하여 실제 운전자를 대상으로 실험평가를 통하여 운전자 의 $\mathrm{AHS}$ 차량 조작 중 운전자의 생리적 특성 및 감성을 분석하였다.

\section{3. 실험 장치 및 방법}

\section{1 생체 신호 측정을 위한 장비}

운전자의 생리적 변화를 관찰하기 위하여 생체신호 측정 장비인 Biopac의 MP 100 system을 이용하여 EEG, ECG, GSR 등을 측정하여 운전자의 생체신호를 검출하여 정신 적 부하를 측정 및 분석하였다.

$\mathrm{EEG}$ 신호 측정을 위하여 EEG electrode cap을 사용하였고, $\mathrm{EEG}$ 채널 6개(전두엽, 후두엽, 측두엽에 2 군데씩)를 통한 $a, \beta, \theta$, $\delta$ 파를 측정하였으며, 측정부위는 국제표준 전 극부착법을 따랐다. $\mathrm{ECG}$ 측정을 위하여 
$\mathrm{SS} 2$ electrode를 사용하였고, GSR은 SS3 $\mathrm{LA}$ 을 사용하여 왼손의 검지와 중지에 1 개 채널을 사용하여 총 8 개 채널을 통하여 데이 터를 수집하였다. 그림 3 은 피험자가 장비를 부착하고 시뮬레이터에 탑승한 모습을 보여준 다.

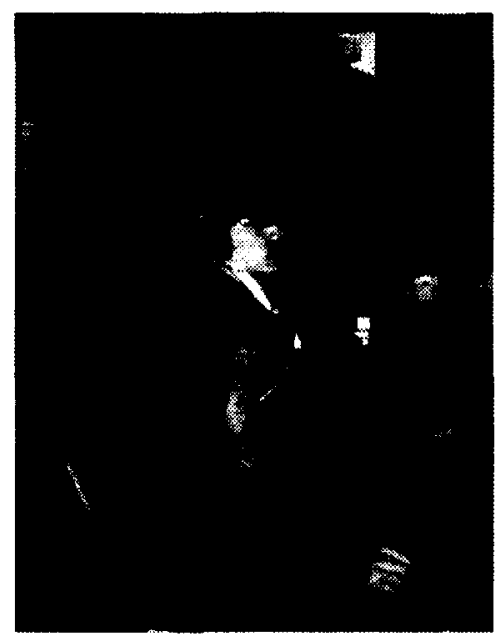

그림 3. 실헙 장면

\section{2 피험자 및 실험 환경}

운전면허증을 소지하고 나이가 평균 23.27 세(표준편차 1.28세)인 남자 대학생 15 명을 대상으로 하였다. 운전 경험은 평균 2.27년 (표준편차 1.62년)이었으며, 피험자는 실험 전에 실험 목적과 내용을 숙지하도록 하였으 며, 실험환경과의 적응을 위하여 실험 전 충 분한 운전연습을 실시하였다. 시뮬레이터에서 주행환경은 낮 시간 동안의 맑은 날씨로 하였 다. 실험실 온도는 $20-23^{\circ} \mathrm{C}$ 로 유지시키고 피험자가 실험에 집중할 수 있도록 소음을 최 대한 줄이도록 하였다. 그림 4는 실험실 내
장착된 실험 장비 및 환경을 나타낸다.

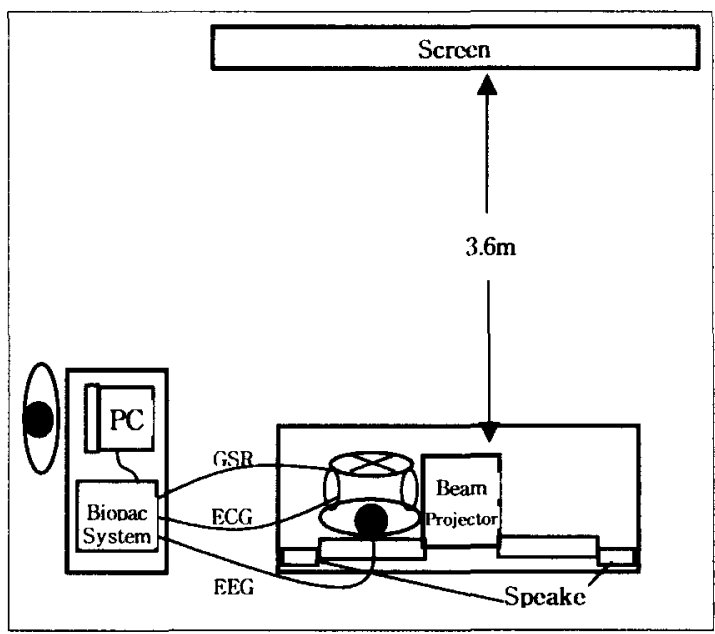

그림 4. 실험 장비 및 환경

\section{3 실험 순서 및 방법}

실험 전 피험자에게 본 연구의 목적과 방법 및 주의 사항 등을 상세히 지시 한 후 5 분간 의 운전을 통하여 실험환경에 충분히 적응하 도록 하였다. 실험 장비를 부착한 후 먼저 현 상태의 신체 상태를 파악하기 위하여 실험 전 $\mathrm{SSQ}$ 를 작성하고, 편안히 휴식을 취하도록 하 였다. 충분한 휴식을 취한 다음 피험자의 안 정상태에서 $\mathrm{EEG}, \mathrm{ECG}$ 및 $\mathrm{GSR}$ 을 측정하였 다. 자동주행 구간의 속도 $120,140,160$ $\mathrm{km}$ 와 차량 간 간격 $5,10,15 \mathrm{~m}$ 을 주행하면 서 생체신호를 측정하였다. 또, 자동주행 구 간에서 피험자에게 30 초 동안 10 개의 곱셈연 산을 부여하고, 피험자는 제시된 곱셈의 정답 을 구두로 말하게 하여 Secondary task에 대한 정신부하가 가중된 구간의 생체신호와 실험 전 안정상태의 생체신호를 비교하였다. 
실험이 끝난 후 각 속도 및 간격에 대하여 $\mathrm{SSQ}$ 와 감성형용사 평가를 하였다. 실험 순서 는 그림 5 와 같다.

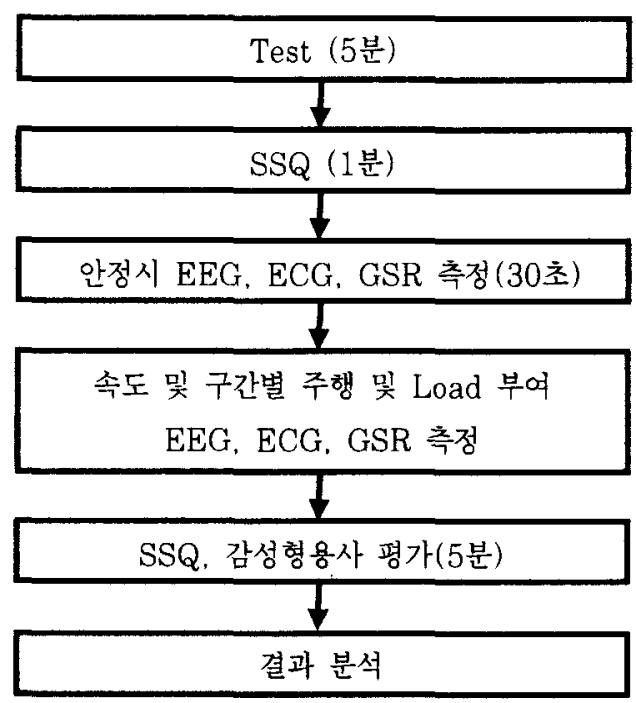

그림 5. 실험 순서

\section{4. 연구 결과 및 분석}

\subsection{SSQ (Simulator Sickness Questionnaire)}

$\mathrm{SSQ}$ 는 메스꺼움 $(\mathrm{N})$, 방향감각 상실 $(\mathrm{D})$, 안구운동의 불편 $(\mathrm{O})$ 등 3 가지 항목과 이 3 가지 항목에 가중치를 부여하여 종합한 TS(Total Score)로 구성되었다. 본 연구에 서는 $\mathrm{SS}$ 를 측정하기 위하여 16 개의 증상과 실험자가 주관적으로 중요히 여기는 2 개의 항목(창백해짐, 나른함)을 첨부하여 총 18 개 의 항목에 대한 $\mathrm{SSQ}$ 의 증상(표 2)을 알아보
표 2. SSQ항목

\begin{tabular}{|c|c|c|c|c|c|}
\hline No & 항목 & No & 항목 & No & 항목 \\
\hline 1 & $\begin{array}{c}\text { 일반적인 } \\
\text { 불편 }\end{array}$ & 8 & $\begin{array}{c}\text { 구역질 } \\
\text { (메스꺼움) }\end{array}$ & 15 & $\begin{array}{l}\text { 위의 } \\
\text { 불편 }\end{array}$ \\
\hline 2 & 피로 & 9 & 집중력 장애 & 16 & 트림 \\
\hline 3 & 두통 & 10 & $\begin{array}{c}\text { 머리가 꽉 찬 } \\
\text { 느낌 }\end{array}$ & 17 & 창벼해잠 \\
\hline 4 & 눈의 피로 & 11 & $\begin{array}{l}\text { 시야가 } \\
\text { 흐려짐 }\end{array}$ & 18 & 나른합 \\
\hline 5 & $\begin{array}{c}\text { 눈 초점 } \\
\text { 장애 }\end{array}$ & 12 & $\begin{array}{c}\text { 어지러움 } \\
\text { (눈뜬 상태) }\end{array}$ & & \\
\hline 6 & $\begin{array}{c}\text { 타액(침)분 } \\
\text { 비 중가 }\end{array}$ & 13 & $\begin{array}{c}\text { 어지러움 } \\
\text { (눈감은 } \\
\text { 상태) }\end{array}$ & & \\
\hline 7 & 땀(식은땀) & 14 & 현기종 & & \\
\hline
\end{tabular}

았다. 모든 항목을 4 등급으로 나누어 피험자 에게 증상의 심한 정도를 체크하도록 하였다 (0: 전혀 느낌이 없다, 또는 느낄 수 없다. 3: 심하다 또는 많이 느낀다.)(Jon R. Bloomfied, 1998).

$\mathrm{SSQ}$ 의 결과를 요인 분석한 결과에서 각 증상의 Varimax loading 값이 0.3 이상인 경우 1 의 가중치를 부여하고 0.3 미만인 경 우는 0 의 가중치를 부여하였다. $\mathrm{SSQ}$ 의 각 증상군의 점수는 각 증상별로 $0 \sim 3$ 까지의 숫 자로 레이팅 된 값에 각각의 가중치를 곱하여 그 합계를 구하고 그 합계에 특정계수를 곱하 여 구하였다. 종합점수는 그 합계들을 모두 더한 후에 특정계수 값을 곱하여 구하였다 (Kennedy etc., 1993). 
속도가 증가할수록 TS(Total Score)값이 증가하는 경향은 있으나 통계적으로 유의하지 는 않았다 $(\mathrm{p}>0.05)$. 또, 피험자들의 실험전 과 실험후의 TS 변화에서도 통계적으로 유의 하지 않게 나타났기 때문에 피험자 모두의 데 이터를 분석에 포함시켰다( $p>0.05)$.

그림 6 은 모든 피험자들의 실험전과 각 속 도별 SSQ에 대한 TS을 나타낸다.

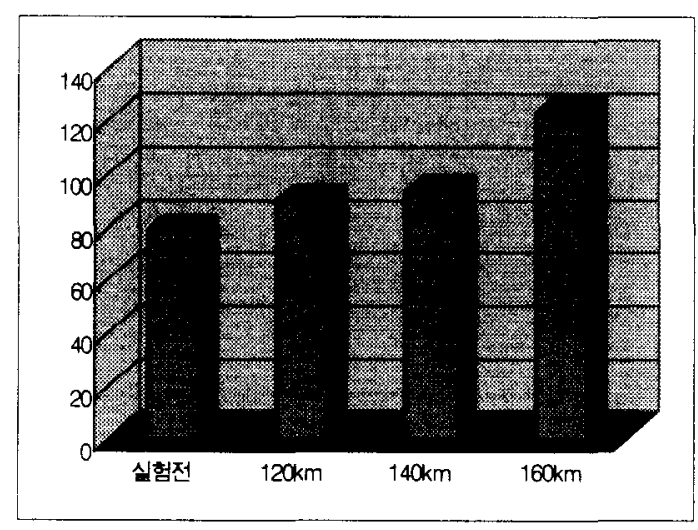

그림 6. SSQ에 대한 TS

\section{2 생체신호 분석}

Biopac system을 통하여 수집된 EEG, $\mathrm{ECG}, \mathrm{GSR}$ 등은 Biopac의 자체 분석 시스 템인 AckqKnowledge version 3.5.7을 사용하여 분석하였고. FFT(Fast Fourier Transfor- mation) 분석을 통하여 시간대역 에서 뇌파의 주파수 대역별 $(\delta, \theta, a, \beta)$ 상대 power spectrum을 구하였다. SD법은 SAS version 8.1을 사용하여 요인분석(Factor Analysis) 을 실시하였다.

$\mathrm{EEG}$ 신호는 개인적 특성이나 긴장상태에
따라 각각 다르게 반응하기 때문에 특별한 수 치 보정 없이는 의미가 없다고 판단하여, $\mathrm{EEG}$ 각 파와 GSR 값에 대하여 측정구간의 값(Measured Value)에서 실험 전 안정상태 의 값(Relax Value)을 뺀 값(Normalized Value)으로 분석을 실시(식 1)하였다. 또. $\mathrm{ECG}$ 의 frequency 값은 $(\mathrm{LF}+\mathrm{MF})$ 값을 $\mathrm{HF}$ 의 값으로 나누어 교감신경과 부교감신경 의 활성화를 알아보았다(식 2).

MV(Measured Value) - RV(Relax Value)
$=$ NV(Normalized Value) - . 식 1.

$(\mathrm{LF}+\mathrm{MF}) / \mathrm{HF} \quad \cdots \cdot \cdot \cdot$ 식 2.

표 3. 뇌파의 주파수 범위

\begin{tabular}{|c|c|}
\hline 종 류 & 주파수 범위 $(\mathbf{H z})$ \\
\hline 델타파 $(\delta)$ & $0.5 \sim 4$ \\
\hline 쎄타파 $(\theta)$ & $4 \sim 8$ \\
\hline 알파파 $(\mathrm{a})$ & $8 \sim 13$ \\
\hline 베타파( $(\beta)$ & $13 \sim 30$ \\
\hline
\end{tabular}

표 4. 주파수 성분과 자율신경계와의 관계

\begin{tabular}{|c|c|c|c|}
\hline 주기 성분 & $\begin{array}{c}\text { 주파수 } \\
\text { 매역 }(\mathrm{Hz})\end{array}$ & \multicolumn{2}{|c|}{ 관계되는 신경계 } \\
\hline $\begin{array}{c}\text { LF } \\
\text { (Low } \\
\text { Frequency) }\end{array}$ & $\begin{array}{c}0.04 \text { - } \\
0.08\end{array}$ & $\begin{array}{l}\text { 혈관운동. } \\
\text { 온도조절 }\end{array}$ & 교감 \\
\hline $\begin{array}{c}\text { MF } \\
\text { (Middle } \\
\text { Frequency) }\end{array}$ & $\begin{array}{c}0.08 \sim \\
0.15\end{array}$ & $\begin{array}{c}\text { 압력수용기 } \\
\text { 반사 혈압 } \\
\text { 조절계 }\end{array}$ & 신경 \\
\hline $\begin{array}{c}\text { HF } \\
\text { (High } \\
\text { Frequency) }\end{array}$ & $\begin{array}{c}0.15 \sim \\
0.4\end{array}$ & 호흡계 & $\begin{array}{l}\text { 부교감 } \\
\text { 신경 }\end{array}$ \\
\hline
\end{tabular}


또, 각 피험자들은 시뮬레이터 주행으로부터 sickness를 느낄 수 있으므로 실험 전·후의 $\mathrm{SSQ}$ 를 비교하여 유의한 차이가 나타난 경우 생체신호에 큰 영향을 줄 수 있기 때문에 유 의한 피험자의 생체신호는 전체 실험 데이터 분석에서 제외시켰다. 표 3은 뇌파의 주파수 대역별 구분을 나타내며, 표 4는 $\mathrm{ECG}$ 를 통 한 자율신경계의 분석 방법을 나타내었다.

\subsubsection{AL 주행에서의 안정상태에 따른 생체신호 분석}

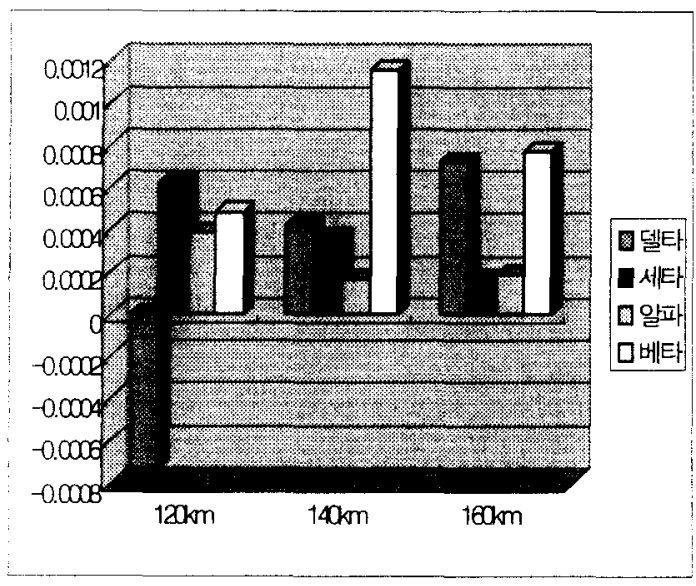

그림 7. AL Relax 구간의 속도에 대한 주파수 대역별 뇌파

그림 7은 자동주행 구간의 안정상태(AL Relax)에서 각 속도별 발생 뇌파를 측정(MV) 한 후 실험 전 안정상태의 뇌파 값 $(\mathrm{RV})$ 을 빼 준 $\mathrm{NV}$ 의 값들에 대한 평균을 보여준다.

분산분석의 결과 각 속도별 뇌파 간에는 통 계적으로 유의하지 않는 것으로 나타났다 (p>0.05). 그러나 수치상으로 미세한 차이가 실제 상황에서는 정신적 부하에 크게 영향을

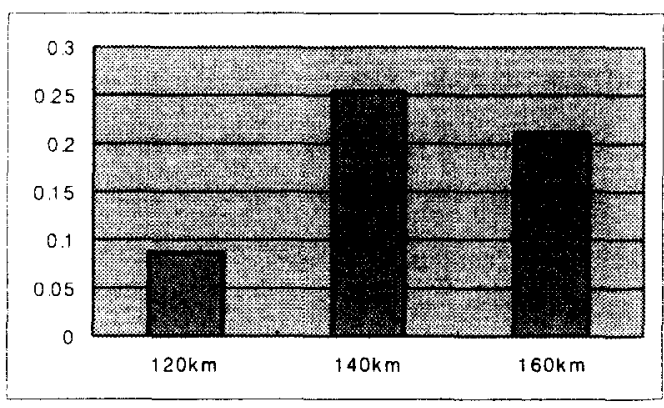

그림 8. AL Relax 구간의 GSR

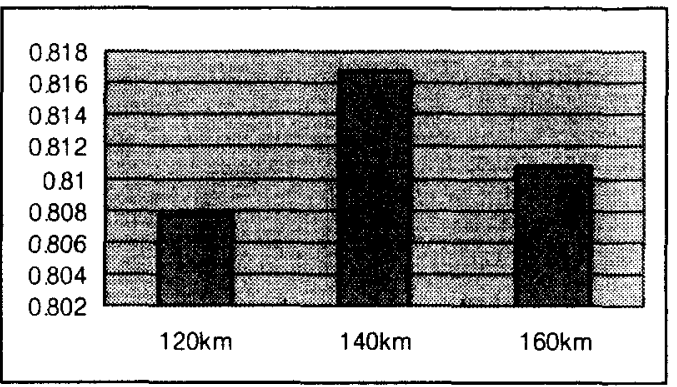

그림 9. AL Relax 구간의 R-R 간격

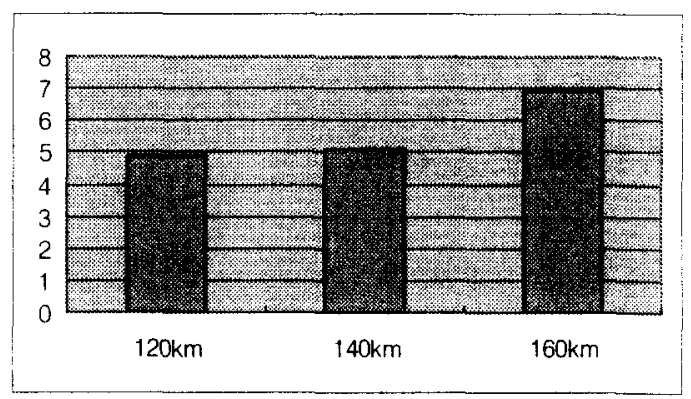

그림 10. AL Relax 구간의 (LF+MF)/HF

줄 수 있기 때문에 간과할 수 없는 부분이다. 각 뇌파간의 평균 증감을 보면 안정적일 때 나타나는 a파가 $120 \mathrm{~km}$ 일 때 가장 높게 나타 났으며, 일반적인 즐거움 상태에 나타나는 $\theta$ 파도 역시 $120 \mathrm{~km}$ 일 때 가장 높게 나타났다. 
정신활동이 많을 때 나타나는 $\beta$ 파는 $140 \mathrm{~km}$ 와 $160 \mathrm{~km}$ 에서 높은 것으로, 부정적 혹은 지 루함에서 나타나는 $\delta$ 파는 $120 \mathrm{~km}$ 에서 현저하 게 낮게 나타났으며. $160 \mathrm{~km}$ 에서는 높게 나 타났다. 특히, $140 \mathrm{~km}$ 에서는 $\beta$ 파가 가장 높 게 나타났는데, 수동주행 구간에서 $100 \mathrm{~km} / \mathrm{h}$ 의 속도로 주행 후 속도 변화에 따른 시각 정 보를 인식하기 위하여 정신활동에 부하가 많 이 걸린 것으로 사료된다. $160 \mathrm{~km}$ 에서는 $\beta$ 파 가 줄어들었고, $\delta$ 파는 증가하는 경향을 보였 다. 이는 $160 \mathrm{~km}$ 의 실험을 마지막으로 하였 기 때문에 피험자들이 $140 \mathrm{~km}$ 에서 주행환경 에 조금 익숙해졌기 때문으로 고려할 수 있 다. 이러한 의미에서 보면, 속도별로 운전자 가 느끼는 부하는 통계적 의미 $(\mathrm{p}>0.05)$ 는 없 으나, 운전자의 미세한 감정과 운전에서 오는 미세한 감성은 수동주행에서 오는 정신적 부 하가 $120 \mathrm{~km}$ 의 자동주행에서 정신적으로 안 정되었다는 것을 의미하며, $\delta$ 파의 감소로 피 험자가 거의 지루함 등을 느끼지 않는다는 것 을 알 수 있다. 따라서 $140,160 \mathrm{~km}$ 의 고속 주행 시에는 속도의 증가에 따른 주위 환경의 빠른 변화가 운전자에게 정신활동을 활성화시 켜 불안을 주었다고 판단된다. 운전자들은 $120 \mathrm{~km}$ 일 경우 가장 안정적으로 느끼고 속도 가 높아질수록 안정적이지 않다는 결론을 낼 수 있다.

그림 8 의 $\mathrm{GSR}$ 의 $\mathrm{NV}$ 값을 보면 $120 \mathrm{~km}$ 의 경우 안정상태와 거의 변화가 없다는 것을 알 수 있다. 그림 9 의 $\mathrm{ECG}$ 의 평균 R-R 간 격에서도 $120 \mathrm{~km}$ 일 때 가장 낮게 나타넜고, 그림 10 의 $\mathrm{ECG}$ 에서 $(\mathrm{LF}+\mathrm{MF}) / \mathrm{HF}$ 값을 비교하였을 경우에도 $120 \mathrm{~km}$ 에서 가장 낮게
나타났으며, $160 \mathrm{~km}$ 에서는 가장 크게 나타났 다. 따라서 교감신경계의 활성이 $160 \mathrm{~km}$ 일 때 가장 큰 것으로 보아 ECG 및 GSR의 결 과가 일관된다는 것을 알 수 있다.

\subsubsection{AL 주행에서의 Load 부하에 따른 생체신호 분석}

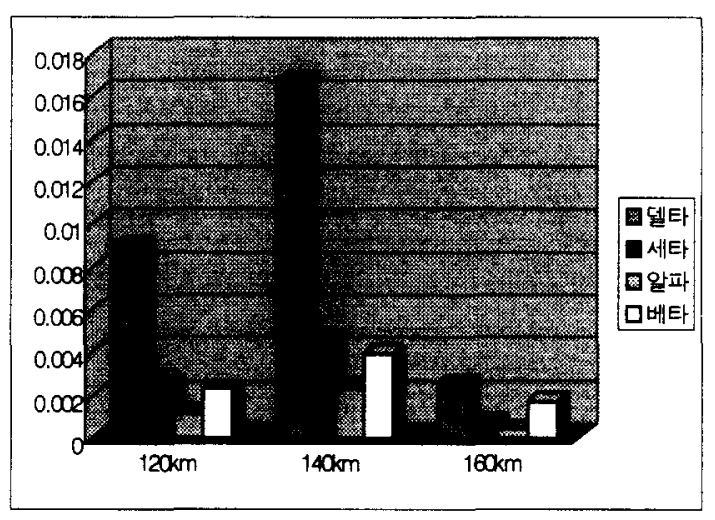

그림 11. Load 부하시 주파수 대역별 뇌파

자동주행 구간에서 피험자에게 간단한 곱셈 load를 부하(AL Load)하여 속도별 생체신 호를 분석하였다. 분산분석의 결과 각 속도별 뇌파 간에는 통계적으로 유의하지 않는 것으 로 나타났다( $p>0.05)$.

본 실험에서 그림 11 과 같이 $160 \mathrm{~km}$ 일 때 모든 파형에서 가장 적게 나타났기 때문에 실 험 전 안정상태와 거의 유사하다는 것을 알 수 있다. 이는 AL Relax 구간과는 상반되는 결과인데, 곱셈 load가 피험자에게 너무 쉽게 작용하여 정신적 load가 미미하였을 경우와 자동운행 구간에서 운전이라는 load가 없기 때문에 피험자의 안정된 기분에 기인하였다고 판단된다. 


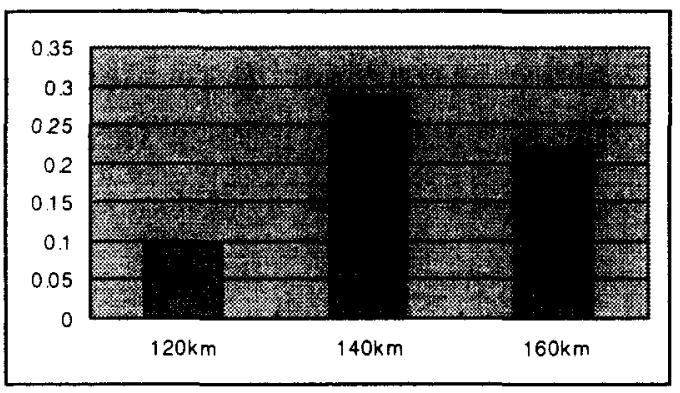

그림 12. AL Load 구간의 GSR

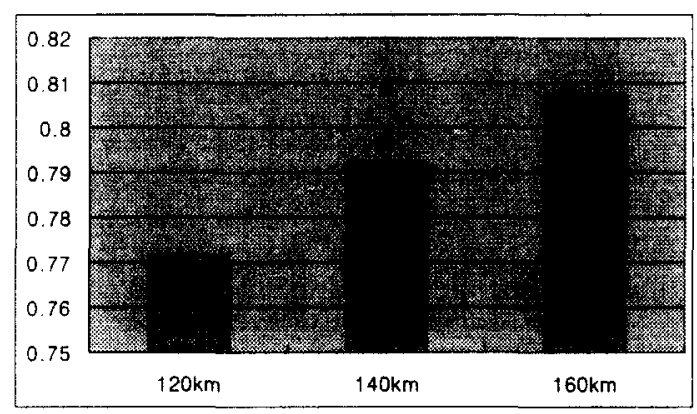

그림 13. AL Load 구간의 R-R 간격

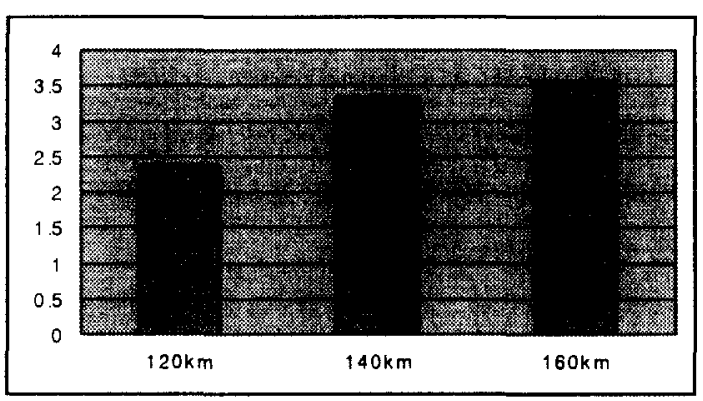

그림 14. AL Load 구간의 ( $\mathrm{LF}+\mathrm{MF}) / \mathrm{HF}$

$\mathrm{GSR}$ 의 NV 값들은 그림 12에서 나타난 바와 같이 $\mathrm{AL}$ Relax일 때 보다 조금씩 증가 하였다. 이는 간단한 load의 부하로 피험자들 이 안정 상태일 때 보다 긴장을 했기 때문이 다. 평균 $\mathrm{NV}$ 값은 $120 \mathrm{~km}$ 일 때 가장 낮고,
$140 \mathrm{~km}$ 의 경우에 가장 높게 나타났다. 따라 서 $120 \mathrm{~km}$ 의 주행 시 피험자의 긴장도가 가 장 낮은 것을 알 수 있다.

$\mathrm{AL} \mathrm{Load}$ 구간의 $\mathrm{R}-\mathrm{R}$ 간격 역시 그림 13 과 같이 $120 \mathrm{~km}$ 일 때 가장 낮게 나타났고, 속도가 증가할수록 증가하는 경향을 보였다.

교감신경과 부교감신경의 활성화 정도를 알 수 있는 $(\mathrm{LF}+\mathrm{MF}) / \mathrm{HF}$ 값도 그림 14 와 같 이 $120 \mathrm{~km}$ 일 때 값이 가장 낮게 나타났다. 따라서 부교감신경이 교감신경보다 활성화되 었다는 것을 알 수 있으며, 속도의 증가에 따 른 교감신경계가 활성화되었다는 것을 알 수 있다.

\subsection{SD법}

\section{(Semantic Differential Method)}

5단계 척도로 나누어 조사된 감성어휘를 SAS version 8.1을 사용하여 차량군 내에서 자동주행 시 피험자가 속도와 거리에 따라 느 끼는 감성형용사에 대한 요인분석을 실시하였 고, SD법을 이용하여 분석하였다.

mineigen 옵션에 의해 고유값(eigenvalue)이 1이상인 요인을 선정하였고, 요인 간에 높게 적재되는 변수의 수를 줄여서 요인 의 해석을 쉽게 하기 위하여 직교회전 (Orthogonal Rotation) 방법 중에 하나인 varimax 회전을 실시하였다.

각 요인들에 대한 요인부하량이 0.6 이상인 값들을 선정하여 속도별 비교를 위하여 중요 도가 높은 factor 1 3까지만 나타내었다. 분석으로 도출된 감성요인 변수들에 대하여 연관된 감성 어휘들을 나열하여, 각 factor들 
에 대한 대표 형용사를 선정하였다.

\subsection{1 속도에 따른 SD 분석}

$120 \mathrm{~km}$ 의 감성형용사 평가 분석결과 총 13 개의 요인으로 나누어졌으며, factor 8 까 지의 누적설명정도(cumulative)가 $32 \%$ 였다. $140 \mathrm{~km}$ 의 감성형용사는 총 13 개 의 요인으로 분석되었으며 factor 9 까지의 누적설명정도가 $89.83 \%$ 였으며, $160 \mathrm{~km}$ 는 총 14 개의 요인으로 분석되었고, factor 9 까 지의 누적설명정도는 $89.27 \%$ 였다.

표 5 의 속도별 대표 형용사를 비교해보면, $160 \mathrm{~km}$ 에 비하여 저속인 $120 \mathrm{~km}$ 의 주행에서 박력감 및 활동감 등의 운동감을 볼 수 있다. $160 \mathrm{~km}$ 의 고속 주행 실험에서는 시각 정보의 빠른 변화 때문에 피험자들이 졸림으로 인한 speed를 느끼지 않은 곡선감 또는 안정감 등 을 볼 수 있다. $140 \mathrm{~km}$ 에서는 고급감과 신선 감, 운동감 등이 나타났다. 생체신호 결과와 비교한다면, 20 대 젊은 층의 피험자들을 대 상으로 하였기 때문에 운동감과 신선감이 잘 나타난 $120,140 \mathrm{~km}$ 가 피험자들의 감성에 적합하다고 사려 된다.

\subsection{2 거리에 따른 $\mathrm{SD}$ 분석}

$5 \mathrm{~m}$ 의 요인분석 결과 총 요인이 14 개로 나 누어졌으며, 누적설명정도가 factor 8까지 $88.71 \%$ 이었고, $10 \mathrm{~m}$ 는 총 13 개의 요인으로 나누어졌고, factor 8 까지 $87.54 \%$ 로 누적설 명도가 나타났다. $15 \mathrm{~m}$ 의 요인분석 결과는, 총 13 개의 요인과 factor 8 까지 $88.71 \%$ 의 누적설명정도가 나타났다.
표 5. 속도에 따른 $\mathrm{SD}$ 분석 결과

\begin{tabular}{|c|c|c|}
\hline 속도 & Factor & 대표 형용사 \\
\hline \multirow{4}{*}{$120 \mathrm{~km}$} & 1 & 박력감, 불안감, 활동감 \\
\cline { 2 - 3 } & 2 & 쾌적감, 균형감 \\
\hline \multirow{4}{*}{$140 \mathrm{~km}$} & 3 & 차별감, 매력감 \\
\cline { 2 - 3 } & 1 & $\begin{array}{c}\text { 신선감, 혁신감, 단순감, } \\
\text { 활동감, 고급감 }\end{array}$ \\
\cline { 2 - 3 } & 2 & 운동감 \\
\hline \multirow{4}{*}{$160 \mathrm{~km}$} & 3 & 활동감, 혁신감 \\
\cline { 2 - 3 } & 1 & 활동감, 운동감, 불안감 \\
\cline { 2 - 3 } & 3 & 안정감, 곡선감 \\
\hline
\end{tabular}

표 6. 거리에 따른 $\mathrm{SD}$ 분석 결과

\begin{tabular}{|c|c|c|}
\hline 거리 & Factor & 대표 형용사 \\
\hline \multirow{3}{*}{$5 \mathrm{~m}$} & 1 & 신선감, 혁신감, 쾌적감 \\
\hline & 2 & 안락감, 단순감 \\
\hline & 3 & 활동감 \\
\hline \multirow{3}{*}{$10 \mathrm{~m}$} & 1 & $\begin{array}{c}\text { 신선감, 혁신감, 균형감, } \\
\text { 쾌적감. 운동감 }\end{array}$ \\
\hline & 2 & 공간감 \\
\hline & 3 & 안정감, 안락감 \\
\hline \multirow{3}{*}{$15 \mathrm{~m}$} & 1 & $\begin{array}{c}\text { 신선감, 혁신감, 균형감, } \\
\text { 캐적감, 운동감, 차별감. } \\
\text { 활동감 }\end{array}$ \\
\hline & 2 & $\begin{array}{c}\text { 안정감, 쾌적감, 안락감, } \\
\text { 곡선감 }\end{array}$ \\
\hline & 3 & 공간감 \\
\hline
\end{tabular}

표 6의 거리별 피험자가 갖는 대표 형용사 를 비교해보면, $10 \mathrm{~m}$ 와 $15 \mathrm{~m}$ 에서 피험자들이 공간감에서 오는 안정감을 느낄 수 있고, 앞 차량과의 거리가 $5 \mathrm{~m}$ 에서 보다는 거리상의 여 유에서 오는 균형감이나 활동감, 안정감 등이 
표현되었다. 실제, 실험 후 피험자들이 $5 \mathrm{~m}$ 의 거리에서 조금 답답하다고 호소하였다.

\section{5.결론 및 고찰}

본 연구에서는 $\mathrm{AHS}$ 의 인간공학적 설계를 위한 실적용 driving simulator를 개발하여 $\mathrm{AL}$ 주행 시 차량군 내에서의 차량간 속도와 거리를 평가하고 운전자에게 적합한 결과를 제시하였다. 본 연구 결과를 실제 $\mathrm{AHS}$ 에 적 용하자면 여러 물리적 제약이 따를 수 있겠으 나, $\mathrm{AHS}$ 에서 운전자의 정신적 부하에 관한 사전적 연구에 의의를 두었다. 본 연구를 발 판으로 보다나은 인간공학 평가용 AHS 시뮬 레이터를 개발하여 $\mathrm{AHS}$ 에서의 환경에 대한 실험 및 구조설계에 대한 $\mathrm{DB}$ 구축과 한국운 전자 특성의 $\mathrm{DB}$ 구축을 통하여 타 분야에 활용하여야 할 것이다.

$\mathrm{AHS}$ 구축에서 성공에 관계하는 가장 중요 한 요소 중의 하나는 사용자의 요구와 선호를 만족시키는 사용자의 수용성과 교통의 안전이 다. 그러므로 본 연구에서 실시한 차량군에서 의 자동차의 거리와 속도에 관한 사용자의 반 응을 연구하는 것이 반드시 필요한 것이다. 이러한 연구는 교통 기술자들의 경험과 전문 가 의견의 조합을 통한 $\mathrm{AHS}$ 를 설계하는 데 유용하게 사용되어질 수 있고, 인간요소의 표 준과 가이드라인의 설계에 기초가 될 것이다.

\section{참고 문헌}

김도회, 자동차 모의 운전환경에서 Simulator Sickness의 정량화 기법 개발 및 분 석에 관한 연구, 박사학위논문, 1998.

강선모, 감성적 요소와 디자인 형상간 Mapping을 위한 감성 해석기 개발에 관한 연구, 공학 석사학위 논문, 2000. 고한우 외, 생리신호를 사용한 단조 작업 수 행시 정신 피로도의 측정과 평가, 한국감 성과학회, Vol.3, No.1, pp.1 6, 2000.

민병찬, 정순철, 김상균 외, 운전 및 도로 상 황에 따른 자율신경계의 반응, 한국감성 과학회, Vol.2, No.1, 1999.

신용균 외, 고속도로 기하구조가 운전자 운전 행동에 미치는 영향. 도로교통안전협회. 96-13-286, 1996.

신용균 외, 여행시간과 속도가 운전자 운전부 하에 미치는 영향, 도로교통안전협회.

95-14-261, 1995.

이봉건, 정인원, 김재진, 신철진, 심상자극과 $\mathrm{GSR}$ 의 관계에 대한 예비연구, 한국감성 과학회 학술대회, pp. 233 237, 1997.

이순요, 양선모, 感性工學, 청문각, 2000. 전용욱 외, 가변형 자동차 제어장치를 이용한 운전자의 주관적 조작 특성에 관한 연구. 대한설비관리학희 5권 3호, pp.69 79, 2000.

한국표준과학연구원, 종합적 생리신호 측정 해석시스템 개발, 과학기술부, KRISS- 
98-094-IR, 1998.

AHS Driver-Vehicle Interface의 Human

Factors 평가를 통한 운전자 영향 분석 및 행동 모델링에 관한 연구. 아주대학 교, 2000년 ITS R\&D 사업 보고서, 2000 .

Anthony Hitchcock, Layout, Design and Operation of a Safe Automated Highway System. California PATH Research Report. UCB-ITS-PRR- 95-11, 1995.

Bin Ran, Kwun Yee Kenny Lee, and Haikun Dong, Cost-Benefit Analysis on Deployment of Automated Highway Systems. Paper No.970906, Transpor- tation Research Record 1588.

Doo-Won Cha, Poem Park, Research of Human Factors Application and its Standards Trends in ITS, 대한교통 학회지, Vol.16, No.2, 1998.

Iowa Univ., Human factors in the AHS: Transferring control to the driver.

Iowa Univ., Driving Performance After an Extended Period of Travel in an AHS, 1998.

IRTAD(International Rroad Traffic and Accident Database), 1999

Jose M. del Castillo, David J. Lovell. and Carlos F. Daganzo, Technical and Economic Viability of Automated Highway Systems,
Paper No.970082, Transportation Research Record 1588.

Jon R. Bloomfied et, Driving Performance After an Extended Period of Traverl in an Automated Highway System, Federal Highway Administration, 1998.

Kennedy, R.S., Lane, N.E., Berbaum, K.S., Lilienthal, M.G., A Simulation Sickness Questionnaire (SSQ): A new method for quantifying simulator sickness, The International Journal of Aviation psychology, Vol.3, Iss.3, pp.203 220, 1993.

Peom Park, Doo Won Cha, Yong Wook Jeon, Driver's Performance and Workload Comparisons between Pre- $^{-}$and Post- AHS Driving, 8th ITS World Congress, Paper No.00217. 2001. 


\section{저자 소개}

\section{전용욱}

계명대학교 산업공학과 공학학사, 아주대 학교 산업공학과 공학석사. Keio 大學 박 사과정, 관심분야는 감성공학, $\mathrm{AHS}$, HMI 등.

\section{$\diamond$ 박 범}

아주대학교 산업공학과 졸업, 미국 Ohio Univ. 산업공학 석사. Iowa State Univ. 산업공학과 박사. 한국전자통신 연 구소에서 HMI 선임 연구원 역임 ('93-95). 현 아주대학교 산업공학과 부 교수. 주요관심 분야는 인간공학, 감성공 학, $\mathrm{HCI}$, 설비안전.

논문접수일 (Date Received): 2002/09/16

논문게재승인일(Date Accepted): 2003/02/04 